\title{
Mainstream Russian Nationalism and the "State-Civilization" Identity: Perspectives from Below
}

\author{
Matthew Blackburn* (D) \\ The Institute of Russian and Eurasian Studies, Uppsala University, Sweden \\ *Corresponding author. Email: matthew.blackburn@ires.uu.se, matthew.blackburn@btinternet.com
}

\begin{abstract}
Based on more than 100 interviews in European Russia, this article sheds light on the bottom-up dynamics of Russian nationalism. After offering a characterization of the post-2012 "state-civilization" discourse from above, I examine how ordinary people imagine Russia as a "state-civilization." Interview narratives of inclusion into the nation are found to overlap with state discourse on three main lines: (1) ethno-nationalism is rejected, and Russia is imagined to be a unique, harmonious multi-ethnic space in which the Russians (russkie) lead without repressing the others; (2) Russia's multinationalism is remembered in myths of peaceful interactions between Russians (russkie) and indigenous ethnic groups (korennyye narodi) across the imperial and Soviet past; (3) Russian culture and language are perceived as the glue that holds together a unified category of nationhood. Interview narratives on exclusion deviate from state discourse in two key areas: attitudes to the North Caucasus reveal the geopolitical-security, post-imperial aspect of the "statecivilization" identity, while stances toward non-Slavic migrants in city spaces reveal a degree of "cultural nationalism" that, while sharing characteristics with those of Western Europe, is also based on Sovietframed notions of normality. Overall, the article contributes to debates on how Soviet legacies and Russia's post-imperial consciousness play out in the context of the "pro-Putin consensus."
\end{abstract}

Keywords: nationalism; ethnicity; post-Soviet; national identity; interviews

\section{Introduction}

Historian Geoffrey Hosking concluded his seminal work, Russians: Rulers and Victims (2006), by highlighting a series of unresolved questions in Russian national identity: Was the country first and foremost a modified empire with vital responsibilities in Eurasia and the World? Or was it a Russian nation-state, resolved to look within its borders to develop a state for the "Russians" (402-403)? During the past decade, the re-emergence of Russia as an assertive force in world politics has only increased the demand for fresh interpretations of where Russian national identity is going and how this shapes behaviors and policies. In the current period, both within the mainstream media and academia, there is a tendency to present such matters through the prism of a menacing "Russian nationalism," which is viewed as a clear and present danger to world peace and security (Kimberly 2014; The Economist 2016). Indeed, Russia is accused of "ethnic nationalism" (Teper 2015; Alexseev 2016) as it has emphasized Russian Orthodoxy and the ethno-cultural russkii core since 2014. They are also accused of "neo-imperialism" (Kuzio 2015; Van Herpen 2016), namely, rebuilding an empire from the ex-Soviet lands and asserting 19th century "sphere of influence" notions. While this article does not present a rebuttal of these interpretations, it does resist such

\footnotetext{
(C) The Author(s) 2020. Published by Cambridge University Press on behalf of Association for the Study of Nationalities. This is an Open Access article, distributed under the terms of the Creative Commons Attribution-NonCommercial-ShareAlike licence (http://creativecommons.org/ licenses/by-nc-sa/4.0/), which permits non-commercial re-use, distribution, and reproduction in any medium, provided the same Creative Commons licence is included and the original work is properly cited. The written permission of Cambridge University Press must be obtained for commercial re-use.
} 
"bogyman" framing and the application of normative labels, such as "imperialist" and "ethnic nationalist." Instead, it provides a deeper examination of Russia's over-arching narratives on nation-state and multiculturalism - the so-called "state-civilization" turn-and how this resonates with ordinary people.

In taking this approach, I contribute to research into "everyday patriotism" in contemporary Russia (Laruelle 2015; Le Huerou 2015; Goode 2018), treating mainstream nationalism as a product of "discursive formation" (Calhoun 2007, 27): the output of elite actors, cultural products (cinema, literature, etc.), and the media is selectively absorbed and reproduced by ordinary people into a hegemonic nationalist discourse. Rather than viewing people as passive receptors, I treat them as active agents that select, reshape, and reproduce certain elements of the imagined nation. Three themes are central to mainstream visions of the Russian nation in this article: (1) the pervasive influence of Soviet legacies in contemporary conceptualizations of citizenship, nationalism, patriotism, and multiculturalism and integration; (2) the prevalence of discourses emphasizing stability, unity and the avoidance of conflictual narratives on the level of the elite and the masses, something in strong contrast to the culture wars and political polarization of the West; and (3) articulations of a post-imperial consciousness, such as the internalization of "statist" priorities in holding the state together and the reproduction of positive myths on Russia's multi-ethnic past that, unlike in the West, are largely unchallenged by post-colonial or post-modernist critiques. Thus, the article contributes to a deeper understanding of contemporary Russian mainstream nationalism and how the imagined nation contributes to the pro-Putin consensus in contemporary Russia.

\section{The Empirical Approach: Studying the Imagined Nation from Below and Locating Hegemonic Discourses}

Adopting the "discursive turn" in nationalism studies (Anderson 1991; Billig 1995; Finlayson 1998; Calhoun 1997, 2007) allows us to define the nation as "a particular way of thinking about what it means to be a people" (Calhoun 1997, 6). Within a given linguistic and cultural space, certain claimmaking discourses gain more traction in the wider population than others. In Gramscian terms, certain identities and values become "hegemonic" among ordinary Russians not because of state compulsion but because they resonate in discursive terms as common sense positions held by the majority. We should not view actors "from above" as able to mould national identity at will, nor should we see people as passive victims of propaganda. For a set of nationalist discourses to become hegemonic, they should be expressed by ordinary people in terms of what they think is right, fair, normal, and in their interests. For this to occur, such discourses should be sufficiently congruent with pre-existing social and historical memory, cultural repertoires, and everyday life experiences. ${ }^{1}$

Despite the connotations of the term, a "nationalist discourse" often includes narratives on ethno-cultural diversity and inter-ethnic harmony. This article assesses the imagined nation from the perspective of the majority nation, which Anthony Smith referred to as the "core ethnie" or "dominant ethnicity" (Smith 1986, 183; Smith 1991, 39). The symbols and imaginaries of the ethnocultural core are important to understanding the directions and possibilities of nation-building. In the case of the multi-ethnic and multi-confessional Russian Federation, the majority "Russian" nation has two adjectives in Russian language: russkii (an "ethnic" Russian ${ }^{2}$ ) and rossiyskii (a citizen of the Russian Federation regardless of ethnic affiliation). In studying the nationalism of the dominant ethnicity (the russkie), we are examining the "aspiration to justify and explain why the population of the state is a whole entity" (Panov 2010, 87).

\section{Methodology and the Challenges of the Bottom-Up Approach}

In order to trace the kind of narratives and discursive frames commonly employed on the microlevel, I conducted more than 100 semi-structured interviews in three Russian cities and their surrounding regions (Nizhny Novgorod, Moscow, and St. Petersburg) between May 2014 and September $2016 .{ }^{3}$ 
Generic purposive sampling was used to achieve as representative a cross-section of social background, education, and occupation as possible. Extended periods in each site (four months) were essential to setting up the kind of referral chains needed to recruit from diverse backgrounds, such as working-class and older respondents. Interviews were between one hour to 90 minutes in length and sought to probe four different aspects of the imagined nation: historical memory, defining Russianness (who belongs to the nation), attitudes to the political system, and Russia's role in the world. Two generational groups were selected, namely, those who were 18-30 years old at the collapse of the USSR and those who were 20-30 years old at the time of the interview. This allowed an examination of differences in upbringing and life experience, contrasting the last Soviet youth cohort with "Generation Putin," young people who have experienced little other than the rule of the current president and the ruling party United Russia.

One key advantage of face-to-face interviews with small groups and individuals over focus groups or surveys is they represent a more intimate form of interaction good for rapport building and creating an atmosphere conductive to frank conversation. This can reveal what topics people can talk about in consistent ways at length, whereas large scale surveys often contain ticked responses to questions that, in practice, may have very little relevance or meaning to participants (Kosmarskaya and Savin 2016, 133-136). In addition, this approach allowed an inductive approach to the data and far more flexibility than a rigid pre-set hypothesis. Data analysis began with a phase of "open-coding," where data was reexamined, reorganized, and deconstructed into discrete parts by manually searching through the textual material and coding all interesting areas of the data with as few preconceived ideas as possible (Welsh 2002).

It is important to note some deficiencies inherent to this approach. First, there is "dissimulation" (Goode and Stroup 2015, 11): in discussing such topics with an "outsider," respondents may simulate positions they would not normally adopt in everyday life. Second, relying on interview data does not give much insight into possible discrepancies between discourses and actual practices (Goode 2018, 260-261). Although I always asked respondents for examples from their own life experience, identifying ways of observing lived practices and how nationalism enters everyday life remains an important task for future scholarship.

Finally, limitations to the data sample should be noted. The interviews were collected in major cities with more than one million people ( $21 \%$ of the overall population) who have better access to education, more social mobility, and higher potential for political protest and dissent. ${ }^{4}$ Thus, this data sample does not include the voices of the smaller industrial cities and monotowns or the rural hinterland. The focus on European Russia's largest cities means this article cannot test the thesis that state-promoted narratives are more comprehensively absorbed in the Russian glubinka (hinterland). On the other hand, the conclusions of this article are of importance in as far as they represent the most economically advanced and politically active parts of Russia, places likely to be at the forefront of future social and political developments.

Second, as this research focused on the imaginaries of the dominant ethnicity, I made two exclusions in data collection. First, I did not collect interviews from those who had migrated to or spent the majority of their formative years outside of Russia proper. Second, after interviewing some respondents with strong Bashkir and Armenian identities in the Moscow pilot project, I decided not to include those Russian citizens with a strong non-Russian ethnic identity, whether indigenous to the Russian Federation, such as Tatars, Chechens, and Bashkirs, or not (Azeri, Ukrainian). ${ }^{5}$ While this meant losing very interesting and vital perspectives, it allowed me to explore more comprehensively, in a large qualitative sample, how those identifying as russkii and living in urban, European Russia imagine the nation in contemporary conditions across socio-economic and generational lines.

\section{Russian Nation-Building from Above: The Post-2012 Shift to State-Civilization Narratives}

Before unpacking some of the discourses on citizenship, ethnicity, nationhood, and patriotism among ordinary people, it is important characterize recent shifts in state discourse. Although a 
comprehensive reading of narratives from above (which could include how the Kremlin's message is mediated through active mid-level political entrepreneurs, influential media programs, internet memes, and viral YouTube clips) is beyond the scope of this article, here I provide a selective reading of some of the most high-profile state proclamations and documents in the post-2012 period.

Overviews of documents and speeches from Putin's first two terms (2000-2008) often conclude that there is incoherence and ambivalence in questions of nationality and ethnic relations in highlevel state discourse. Oxana Shevel (2011) described them as "purposefully ambiguous" ${ }^{6}$ while Peter Rutland (2010) saw in them the "presence of absence," a conceptual murkiness appealing to different segments simultaneously without cast-iron ideological commitments. Perhaps the most important theme was "statism," the building of a "fully-fledged federal state" to fill the "power vacuum" left by Yeltsin-era decentralization (Putin 2000) that could deliver stability, predictability, and improved living standards as well as halt Russia's slide into third-rate power status. As the first two terms of Putin's presidency were marked by unprecedented economic growth and consumerism, the executive could deliver new levels of stability by establishing its "power vertical" (vertikal vlasti) without abandoning commitment to Yeltsin's Western-influenced rossiyskii "civic" nation concept. By the same token, rather than representing any push for Russification or assimilation, policies, such as the elimination of Yeltsin's bilateral agreements with the Russian regions, the banning of political parties based on ethnic grounds, and the merging of some autonomous regions, are best understood as efforts on the part of the Federal Center to recentralize and the reincorporate the regions (Petrov and Slider 2007; Chirkova 2010; Shcherbak and Sych 2017, 316).

A more substantive change to state discourse took shape during Putin's third presidential term (2012), namely, the shift to the "state-civilization" discourse. Various authors have noted this shift, which cannot be understood as moving clearly to the civic or the ethnic ideal-type of nationhood (Verkhovsky and Pain 2012; Pain 2016; Laruelle 2017; Ponarin and Komin 2018). ${ }^{7}$ The new direction post-2012 should be understood within the context of two key changes in foreign and domestic affairs.

Firstly, Russian foreign policy was recalibrated following Putin's watershed Munich speech (2007) and the Georgia conflict (2008), recasting Russia from a potential partner of the West to an independent, revisionist Eurasian power (Newton 2010; Trenin 2015). Concepts of civilizations in competition and multipolarity were soon promoted to explain this new direction. Secondly, the Bolotnaya protests from 2011-2012 led to changes in the Putinist social contract (Gudkov 2015; Kolesnikov 2015). Authorities moved away from the "creative" and "middle" classes toward a deal with the "poor and state-dependent conservative groups in the provinces" (Gudkov 2015, 864). Thus, social and geopolitical changes demanded a discursive response from the state, which duly emerged in 2012.

A concise overview of the post-2012 "state-civilizational" turn is evident in Putin's programmatic article from January 2012. The article opens with a rejection of Western multiculturalism and civic nation-building - which is perceived to have failed-as well as narrow ethnic nationalism, which is viewed as destructive and primitive. The alternative to this is Russia's "state-civilization" which has three key features. First, Russia has "unique, civilizational" traditions in preserving ethno-cultural diversity and harmony. The Russians (russkie) play the role of the "state-forming people central to the very existence of Russia" whose "great mission" is to "unite and hold together a civilization" in the Eurasian space (Putin 2012a). ${ }^{8}$ As will be seen below, this sentiment reemerges in interview narratives, both in representations of ethnic Russian and native peoples (korennyye narodi) and in myths on the peaceful imperial and Soviet past, where the peaceful integration and unification of "smaller" nations into a large and powerful state is emphasized.

Second, a distinctive type of civic patriotism and unity has been encouraged, which builds on pre-2012 narratives on "state patriotism." In essence, this civic patriotism is apolitical, focuses on the need to avoid radical changes in politics and hold the Russian Federation in one piece despite external pressure and centrifugal internal forces. In the 2013 Valdai Conference, Putin argued that a civic (grazhdanskaya) identity should be developed "on the basis of shared values, a patriotic consciousness, civic responsibility and solidarity, respect for the law, and a sense of responsibility 
for their homeland's fate, without losing touch with their ethnic or religious roots" (Putin 2013). In a subsequent Valdai conference, Putin (2018) clarified his views on nationalism:

Russia emerged as a multinational state... This is the basis of Russia's existence. If we want Russia to be preserved... but overstress some kind of caveman nationalism, sling mud at representatives of other ethnicities (etnosov), we will tear this country down, which is not in the interests of the Russian people (russkii narod)... This is what I mean when I say I am the most genuine and effective nationalist in the country (Putin 2018).

This conservative, state-preserving stance, together with a Soviet-style version of "civic patriotism," also emerges in interview narratives where ethnic nationalism is rejected, patriotism is understood in nonpolitical terms, and there is conservatism on questions of political and social change.

Third, the "state-civilization" identity encourages a certain cultural unity (without forced Russification or reduction of ethnic and cultural diversity) that is required in a multipolar world of geopolitical rivalries and competing civilizational blocs. This unity is provided by Russian language and culture as well as "traditional values".

These pillars of the state-civilization identity are visible in the written and spoken outputs of highlevel state actors (Putin 2012a; Lavrov 2016) as well as in policy documents (Foreign Ministry 2013; Russian Security Council 2014; Ministry of Culture 2015). ${ }^{9}$ In these texts, the focus is on avoiding destabilization and the loss of identity that leads to losing "national unity" and "territorial integrity." It is in this context that the promotion of a neo-traditional discourse attempts to sustain the idea that Russia is civilizationally distinct. The discourse has resulted in a range of post-2012 social policies protecting traditional family values, enforcing respect for religion, and strengthening Russian language and culture (Stepanova 2015; Yablokov 2014, 623). At the heart of much of this has been the Russian Orthodox Church, whose influence and visibility in state discourse continues to grow year by year. Discourse about traditional values positions Russia as the protector of Europe's cherished values at a time when the West itself is viewed as abandoning its own heritage. The urge to unity resonates with what Emil Pain described as imperial nationalism: the obsession of keeping the "imperial body" in one piece, a commitment to Russian exceptionalism (the idea of a special Russian civilization), and the common view that West is the key existential threat to this civilization $(2016,60)$. This "hold-the-fort" statist worldview also emerges in interview data regarding attitudes to the North Caucasus and justifications for keeping the status-quo in the current period.

Thus, it may be argued that a coherent-if eclectic-discourse on Russian civilizational distinctiveness has been propagated by the state since 2012 . The state-civilization identity promotes a common civic identity based on common language, culture, and values but also celebrates ethnocultural diversity: non-Russian minorities keep their unique cultures and the russkie are described as the cement holding the nation together. Having characterized the picture from above, I will now examine interview narratives on national belonging, state, patriotism, and nationalism.

\section{Section One: Inclusive and Harmonic Visions of Russianness in Interview Narratives}

In the following section, I examine three main elements of popularly reproduced harmonic and inclusive Russian identity. Initially, I consider conceptualizations of Russianness, much of which is quite compatible with the state-civilization discourse examined in the previous section. Then, I show how popular myths on the history of Russia as a multi-ethnic state are central to Russia's post-imperial consciousness. Finally, I explore the values behind notions of unity, stability, and peace, which reflect a small-c conservative zeitgeist but do not connect to any clear discourse on traditional values.

\section{The Question of Russianness}

When it comes to how respondents understood the two terms that denote Russianness (russkii and rossiyskii/rossiyanin), only a quarter of respondents reproduced the classic textbook definition that 
russkii is equivalent to nationality (natsional'nost') and rossiyanin is equivalent to citizenship (grazhdanstvo). Those reproducing this dichotomy often had very little else to say on the matter. They seemed to accept the Yeltsin-era concept of rossiyanin and Soviet-style understandings of nationality as a fixed category from birth that was passed on or determined by parents. The other three-quarters of respondents viewed rossiyanin as a dry, formal, and official label lacking real meaning: "The status of the term 'rossiyanin' is rather artificial. I don't understand what a 'Rossiyanin' is. For me the words 'russkii' and 'Rus'" are closer" (Interview with Alexander, a 25 -year-old business development manager, in St. Petersburg). For these respondents, rossiyanin was a political construct with little meaning to them directly that they would not self-apply in any context other than in official documents. Many found little resonance with the statement "I am proud to be a rossiyanin." For members of the older generation, rossiyanin was a "new word" unclear in meaning tied to "the appearance of democracy" and Boris Yeltsin (Interview with Denis, 41-year-old journalist, in Nizhny Novgorod).

Russkii, on the other hand, had a far deeper significance: "the adjective russkii says much more about you then the word rossiyanin, as it is about some kind of very rich history and culture that goes back to our roots" (Interview with Svetlana, a 25-year-old postgraduate sociology researcher, in Nizhny Novgorod). Many pointed out that calling oneself a rossiyanin would be "strange." For example, one respondent said, "rossiyanka for me is more about belonging to a state while russkaya is more about the merging (or unification) of people (ob"yedineniye lyudey) (Interview with Eva, an unemployed, 26-year-old university graduate, in Nizhny Novgorod). It is important to note that this sense of "unification" was not about blood or kinship; being russkii was often described as a "thing of the soul," something one "feels within." ${ }^{10}$ While being a rossiyanin merely refers to those "living on the territory of the Russian Federation," being russkii is about the "soul (dukh)" (Interview with Julia, a 47-year-old assistant in film set production, in St. Petersburg): "For me the meaning of russkii, is not belonging to some family name, such as Ivanov or Petrov, but about what you feel yourself to be from the inside" (Interview with Zakhar, a 29-year-old manager for an export company, in St. Petersburg). The apparent lack of resonance of rossiyain as a category of in-group belonging is paralleled at the level of the state: efforts to promote the slogan "we are all rossiyane" have not taken center stage, and rossiyane has been dropped as a form of address from Putin's presidential speeches since 2005. In contrast, russkii is felt to reverberate back across the centuries and is of far more utility in describing commonality.

In interviews, definitions of Russianness (russkost') tended to underline nonracial criteria in favor of a Russian melting pot: "Russia was never only a russkaya country. Here, everything is intermingled..., so many national groups (natsii) have intermixed that it is impossible to talk of "pure" russkie or "pure" Tatars (Interview with Olga, a 55-year old factory worker from Avtozavodsk, in Nizhny Novgorod). As a result of this intermixing and gradual expansion, "it is impossible to distinguish the russkie from the rest.... Russia has always been a common home. It is an empire, and, like any empire, she absorbs people into her; these people then live together for centuries" (Julia, a 47-year-old assistant in film and set production, in St. Petersburg). This presents Russia as a vast mixing space. Part of being russkii is rejecting the narrow confines of ethnicity and embracing a supra-ethnic, state-centred identity. Marlene Laruelle also noted this "mainstream" use of russkii for denoting "everything Russian," from culture to the "Russian state understood in its historical longue durée" (2016a, 275-276).

Many older respondents argued any ethnic group could be viewed as russkii. What is needed is hard work, loyalty, and service to the state. An excellent demonstration of this sentiment can be seen below in an anecdote about Tsar Alexander III:

The emperor held a large parade with lots of foreign dignitaries. It was all pomp and circumstance... as the regiments marched past one of the ambassadors, came over, and asked the Tsar, "Where are the russkie here?" Alexander replied, "This detachment is made up of Bashkirs. Here we have Byelorussians in the cavalry. But all of them together, all these 
nationalities, together in one place, these are the russkie." (Interview with Andrei, a 51-year old computer programmer, in St. Petersburg)

The setting is pre-Soviet, but, according to the respondent, the story was popularly retold in the late Soviet period. Another commonly presented idea was that, while the term "Soviet" technically described those with Soviet passports, in practice, it was not used as a term to describe groups of Soviet citizens. Instead, according to several respondents, when meeting other foreigners abroad, the tendency for all Soviet citizens, regardless of ethnicity, was to self-define as russkii. This sentiment sheds much light on how the Soviet-era version of russkii as a category of practice still operates among many people. It suggests that, when we zoom in for detail, we find different ethnic groups across Russia. Upon zooming out, we find that all the peoples of Russia are essentially treated as part of the russkii category. As the respondent below indicates, when there is a common purpose, "we all become russkie":

Before there was the Soviet person, but then, after that, everyone was artificially divided into nationalities. It seems to me that rossiyanin and russkii are artificial divisions. If it's Russia then the term to use is russkii. If we take things in isolation, the small peoples (malye narodi), then an inhabitant of Mari El will call himself a Buryat. Well fine, if you are a Buryat then fine, you are a Buryat. But when we all get together, then we are all russkie, like in the train or when we have a drink. (Interview with Elisa, a 58-year-old director of a sports center, in St. Petersburg)

Thus, the sentiment is clear: the respondent perceives herself and others as russkie when there is a common cause. So, russkii can also be understood as a category of practice: when people live alongside one another, interact in Russian language, and follow accepted behaviors, they feel Russian.

\section{Advocacy for a Multinational Russia and Myths on the Imperial and Soviet Past}

Interestingly, the majority of respondents in this research supported the idea that Russia is and should be a multinational country (mnogonatsional'naya strana) and a common home for different national groups (narodov). This appears to be a default position among respondents young and old and is based on the common-sense view that "nationalism is simply not acceptable as a matter of principle" given that "Russia is a very multicultural country (mul'tikul'turnaya strana)" in which "thousands of people (tysyacha narodov) have lived and closely interacted (vzaimodeystvuyut) for many centuries" (Interview with Boris, a 25-year-old TV/radio presenter, in St. Petersburg). Several positive references were made by a range of respondents to the malye narodi (particularly the Tatars, Bashkirs and Yakuts) as "native" (korennyy) to Russia. These people were presented as organic and homegrown (korennyy), having lived compactly alongside the russkie for centuries. Rather than being a threat, "the various peoples of Russia have been pretty complementary to the russkie. I mean they have really got on well with us for hundreds of years... There is harmony" (Interview with Viktor, a 22-year-old International Relations student, in Nizhny Novgorod).

When we turn to how the russkie were imagined in this interethnic family, traces of hierarchy emerged. The Russians are at the top leading the family while the smaller nationalities are content playing their part. This is a harmonious family unit that is imagined through history to the present day:

Russia was formed from many people (narodami). Of course, the Russian people (russkii narod) have been prevalent (prevaliroval) and have led the others with her; it is more intellectual and industrious. That is how things have worked out. But the other people (narodi) are by no means worse. We won the war together-all 15 republics took part, Jews, Azeri, Ukrainians, Belarusians, and Georgians! We have always been multinational (mnogonatsional'nymi). (Interview with Oleg, a 49-year-old construction site foreman, in St. Petersburg)

The view above is founded on a set of narratives on the peaceful absorption of malye narodi into a common space, a process that is led by the Russians. Here, we find powerful myths suggesting these 
people were not oppressed by the central authorities but happily incorporated into Russia's rich multiethnic tapestry. Thus, Russia's multiethnic traditions are imagined to be more peaceful and kind-hearted than the other imperial expansions of the age. Russia's "peaceful" empire building on the Eurasian space was contrasted to the brutal colonization methods of the Western powers:

I think we brought writing, the alphabet, to many people. After all, peoples of the North didn't have anything up to the Soviet period. We founded this for them, and we established their language, in contrast to the Americans who exterminated the native Indian population. Why are they not held to account in this world? (Interview with Igor, a 41-year-old lecturer in International Relations, in Nizhny Novgorod)

The idea of respect is also highlighted, which is combined with ignoring or selectively forgetting Russia's often destructive colonialism in Central Asia and the Caucasus. Instead of occupation or exploitation, there is absorption in terms of respect, with the newly absorbed peoples becoming equal to the russkie: "The question of respect is important. We have never founded colonies for ourselves. We absorbed people (natsii) and these people (natsii) became equal to us" (Interview with Vladislav, a 28-year-old postdoctoral researcher in Middle Eastern studies, in Nizhny Novgorod).

In popular imagination, Russians went out and harnessed wild tundra wastelands, winning over primitive tribes with soft, nonviolent policies of integration. The Russians are portrayed as harbingers of progress, civilization, industrialization, and modernity. Yet, we still find hierarchies on display. Whereas the Russians lead, build, and organize, the natives either learn how to follow or remain backward.

We came and gave education to them and built towns. And if it wasn't for us, they would still be tending to flocks of deer. I don't think we were in any way “occupiers." Everything was different. Men set off across the kilometers, passing tundra, with the wind at their faces as well as the cold. They marched on without seeing anyone for thousands of kilometers, stuck a flag in the ground, and that is how it was declared Russian territory. As for the locals, well, some of them wanted to study, others to stay with the deer. (Interview with Mikhail, a 29-year-old actor, in Moscow)

Thus, these narratives of Russia's natural and peaceful expansion are untroubled by any question of colonialism or imperialism from Russians to non-Russians. As historian Alexander Morrison (2016) pointed out, Russians generally reject accusations of colonialism. This is also visible in popular views of the USSR as a peaceful internationalist society. Although attitudes to other aspects of the Soviet Union differed, there were consistently positive representations of the Soviet policy of druzhba narodov in young and old respondents. Older respondents consistently remembered the late Soviet period they grew up in as one where no difference among national groups was felt and ethnicity was of no importance. This sheds light on how Russians understood the reality behind the Soviet rhetoric on "the Friendship of Nations" (druzhba narodov):

In the period we lived, there was a real friendship of nations... In school, we studied alongside all kinds of nationalities. We didn't see any difference between nationalities. I didn't care about it at all. (Pause) Everyone was friendly with one another. In our courtyard, I don't know, it was like we were all the same. (Interview with Ivan, a 55-year-old retired miner, in St. Petersburg)

There is little evidence that respondents thought non-Russians may have experienced things differently. Speaking from the point of view of the majority nation, older respondents offer positive recollections: "people around me did not worry about nationality... We didn't pay attention to this issue... We all lived peacefully together as a multi-ethnic country" (Interview with Yegor, a 44-year-old newspaper editor, in Nizhny Novgorod). Older respondents argued that this was 
one part of Soviet ideology that people believed in, and, as a result, it functioned well. The imperial and Soviet past was usually presented as normal and, therefore, not something in need of critique. By focusing on the positive aspects of the imperial and Soviet experience, these narratives support the image of Russia as a benevolent force in the Eurasian space. Conspicuous in its absence was any reference to discourses on Russians as the victims of imperial ambitions and overreach, which peaked in the 1980s. Indeed, there was little elaboration of the role of the russkie in either period. In popular understandings of Russia's multi-ethnic past, in keeping with Soviet tradition, the Russian role is not something that is carefully considered or justified but is still commonly understood as that of "elder brother": the group sitting in the senior position among the family of Eurasian ethnic groups. Unlike in Western countries, this way of thinking does not appear to be challenged by any postmodernist or postcolonial critique of the imperial past. Rather than a guilt complex or anguish over the victims of Russian expansion, most can straightforwardly take pride in the historical expansion of the Russian state.

\section{Notions of Unity, Patriotism, and Peacefulness}

One important commonality that emerged in interviews was the juxtaposition of the calm and peaceful patriot as opposed to the malignant and aggressive nationalist, something that has also been found in other qualitative research (Goode 2018, 270). Succinctly put, "a nationalist is a person who is against everyone that is not russkii, while a patriot is a person that is for Russia" (Interview with Sergei, a 40-year-old in a marketing department, in St. Petersburg). Whereas a nationalist is aggressive and noisy, stirring up needless trouble, a patriot has different values, such as "honour, dignity, and love toward the mother land (chest', dostoinstvo, i lyubov' k Rodine)" (Interview with Ilia, a 46-year-old import-export business owner, in Nizhny Novgorod). Nationalists, in contrast, want to debase or humiliate members of other "nations" (natsiia) while trumpeting the merits of their own:

The patriot looks after (zabotitsya) the interests of the country, while the nationalist is one who would probably try to humiliate/degrade (unizit') the dignity of other countries and peoples. The concept of nationalism is more aggressive, while the idea of patriotism is more constructive, moderate, and positive. (Interview with Galina, a 40-year-old in a sociology department, in Nizhny Novgorod)

The above can be understood as a continuation of Soviet discourse that presented nationalism as a pathologic manifestation of racism, xenophobia and fascism ${ }^{11}$, while patriotism was a moderate, normal behavior bringing unity and peace to society. Respondents in this research tended to a definition of patriotism in terms of loyal and peaceful citizens, using language similar to late-Soviet pamphlets on Soviet patriotism and internationalism (Collias 1990; Bezrogov 2012). The image of the calm and loyal patriot who abhors radical action and sudden transformation stands in stark contrast to the radical and aggressive nationalist with messianic plans to reshape the nation. In his research on contemporary patriotism in Russia, Paul Goode reached a similar conclusion: "what really distinguishes a patriot from a nationalist in practice is loyalty to a regime rather than ethnic sentiment" $(2018,275)$. Non-conflictual and often depoliticized stances reflect a conservatism that is indifferent or hostile to transformative visions.

The above discourse on patriotism also involved the question of how to attain unity across the population through the absorption of Russian culture and language, something at the heart of Vladimir Medinsky's “The Foundations of Cultural Policy" (Ministry of Culture 2015), which speaks of the need for a common civilizational identity. As mentioned in the previous section, older respondents tended to portray russkii as an open category that could include almost any citizen who worked hard and lived "normally". In this study, younger respondents also did the same with russkii and tended to see rossiyskii as a superfluous marker. What differentiated younger respondents from older respondents was the way assimilationist demands were framed. The central theme here is that to become russkii one must absorb Russian culture and language as well as gain native familiarity 
with cultural symbols and products. In the example below, the symbolic matryeshka doll is chosen as an object that should feel native to a russkii:

The main thing is to be brought up in the traditions of Russian (russkaya) culture, even if you weren't born here. If Russian (russkaya) culture is not alien to you, if it is in your blood, then you understand what a matryeshka is, not just because you saw in it in a souvenir shop but because it is a native thing for you... [things like] Russian (russkaya) nature, the Russian (russkie) wide-open spaces. (Interview with Marina, a 29-year-old manger in a software company, in St. Petersburg)

Younger respondents tended to draw harder boundaries of inclusion and exclusion along cultural lines. For many, this cultural-linguistic version of Russianness is not something that can be learned in a few years: "to be russkii you need to be brought up in Russian cultural traditions as it is only then you will know the culture, its uniqueness, the identity of the Russian people (russkii narod)" (Interview with Katya, a 22-year-old student of politics, in Nizhny Novgorod). Thus, becoming Russian in cultural and linguistic terms requires significant adaptation time, perhaps even a whole life time: "no person can understand Russia if they have not lived here long enough and not absorbed some of the values that exist in all rossiyskii people, all russkie people" (Interview with Svetlana, a 25-year-old postgraduate researcher in sociology, in Nizhny Novgorod).

The way the respondent above conflates rossiyanin and russkii is an important point. As mentioned in the previous section, most respondents in both age groups subscribe to a nonracial, culturallinguistic understanding of russkii as a category. It became apparent that some not only view rossiyanin and russkii as interchangeable but also see the two terms as artificially dividing a larger group, despite their common traits: "the word rossiyanin suggests that some people are russkie and others not very russkie, but when you just call everyone russkie without any scrutiny, that is more humane" (Interview with Pyotr, a 29-year-old architect, in Nizhny Novgorod). So, we return to the idea russkii should not be used as a marker of ethnicity but to describe citizens of Russia and members of the Russian linguistic and cultural space. Thus, many respondents view rossiyanin and russkii as having similar meanings and submerge or discard the former, preferring russkii as the adjective to describe people of various ethnicities united into a nation with a common language, culture, history, and territory.

While conservativism, quiet patriotism, and the desire for integration around Russian language and culture fits well with state discourse, it is worth highlighting a negative finding: there was very little reproduction of the idea that Russian citizens are united by traditional values that make them distinct from the degenerate West, as propagated by state discourse. Thus, despite the prominent place of the Russian Orthodox Church and consistent efforts to propagate this discourse on state media and on-the-ground activism, my data shows that this narrative is not being internalized or reproduced on the level of ordinary people.

In this research, the majority of respondents justified Russia's distinctiveness from Europe with pragmatic points, such as that Russia must tread "a third path" as she is "too large to enter the EU... And Russia still needs to go through a long period of development to reach this stage" (Interview with Roman, a 28-year-old journalist for Kommersant, in Moscow). As an "enormous country," Russia "must have her own mind and go her own way, and not copy the experience of other countries." She needs "a Tsar" at the head and "effective local rulers" in the regions to hold together "a complex multi-ethnic country with so many regional specifics" (Interview with Marina, a 29-year-old manager for a software company, in St. Petersburg). Thus, advocating that Russia has a unique role in the world often went together with an incoherent sense of Russia's distinct civilizational purpose as well as any deeper basis for this. This is also the picture in quantitative polling, where large numbers $(40 \%)$ are unable to articulate what Russia's special path is, with economic development (29\%) being chosen as the most popular answer (Levada 2016a).

Having examined inclusivist sentiment in Russian mainstream nationalism, I will now turn to exclusivist sentiment and consider what this reveals about the nature of mainstream Russian 
nationalism. Here, two out-groups (not without overlap in status) emerged, namely, people from the North Caucasus and non-Slavic migrants from Central Asia, something that is also reflected in quantitative polling (Levada 2016b, Levada 2018). ${ }^{12}$

\section{Section Two: Exclusivist Sentiment}

\section{The North Caucasus: statist Priorities and the post-imperial Consciousness}

Attitudes to the peoples of the North Caucasus, which consists of eight regions, including the Republic of Dagestan and Chechnya, differed from the warmer sentiments displayed to the other korennyye narodi of Russia, such as the Tartars, Bashkirs, or Yakuts. Three main lines emerged in describing the Kavkaztsy as an Other. They were depicted as (1) rude and ill-behaved, (2) culturally alien and backward, and (3) a drain on resources. Rather than reproducing these stereotypes and schemata in detail here, I will focus on what this reveals on the nature of Russia's post-imperial consciousness.

The majority position among respondents was to support the current status quo with regard to the position of the North Caucasus in the Russian Federation (i.e., providing large subsidies to Chechnya and a free hand for Ramzan Kadyrov in order to achieve regional peace and stability). Notably, arguments in favor of the status quo rarely referred to the principle of Russia as a multiethnic state. Instead, the common-sense understanding of the current state of affairs between the Federal Center and the region is that "the money sent out there is a pay-off (podkup) to the local fighters there, to stop them from turning the place into a slaughterhouse" (Interview with Marina, a 29-year-old manager for a software company, in St. Petersburg). A message that cut across many respondents was the need to contain "a dangerous region with a dangerous people (opasnii narod)" (Interview with Zakhar, a 29-year-old manager for an export company, in St. Petersburg).

Even respondents who lamented the loss of resources, which they argue should instead be spent on their own population, still support keeping the status quo in the North Caucasus: "the subsidies are, in a political sense, probably an inevitable measure; if we want peace on the borders, we will have to give something for this" (Interview with Galina, a 40-year-old in a sociology department, in Nizhny Novgorod). In this sense, differentiation of regions into "ours" and "not-ours" has occurred, but support for retaining the territory remains, which is justified on the lines of state security. Thus, the North Caucasus is presented as a space that must be quarantined in order to contain violent, terroristic, separatist, and even criminal elements. Sending money to this zone helps neutralize it and keep things "spokoino," for "if we don't keep things in order in the Caucasus, those blacks won't let us live (nam zhizni eti chernyye ne dadut)." ${ }^{13}$ However, as long as "there is money for everyone down there (Tam vsem nikakikh deneg ne zhalko)... there is peace, calm among people, development.... And all this is worth it" (Interview with Ludmilla, a 50-year-old head of a university dormitory, in Nizhny Novgorod).

Desire to quarantine the region for security reasons is accomplished by imagining the region as a frontier zone on Russia's southern border, where peace, security, and stability must be achieved. The important point here is the view that if this peace is disturbed or order collapses, the consequences for Russia itself could be disastrous. This sentiment connects the retention of territory with securing peace and stability. In the extract below, the process of gathering these territories is presented as progressive (increasing security), while losing territory is regressive (reducing security):

If we gave Siberia to the Chinese or Karelia to the Finns, this would be like a reversal of historyall the country would be divided into regions, into little kingdoms, who would then fight among themselves... The buffer space we have today holds Russia in a condition of peace (uderzhivayet Rossiyu v sostoyanii mira). (Interview with Daria, a 28-year-old events manager for the local government, in St. Petersburg)

Thus, even if these lands are filled with people that are not theirs, it is their territory, vital to creating a buffer zone around the core Russian lands. This resonates strongly with Emil Pain's 
(2016) view of "imperial nationalism" and the obsession with keeping the imperial body in one piece. According to the version reproduced by my respondents, the loss of these territorial frontier zones could cause Russia itself to break up. This is a kind of domino theory for post-Soviet Russia that sees claims to national self-determination and separatism as a genie that, once released, cannot be restrained, possibly leading to the collapse of the Russian Federation. Here the respondent clearly underlines that, even though his gut feeling is to let the North Caucasus secede, his head tells us this is not in the "interests of the state":

I can say in the nineties one position was strong: just put a fence up there [in the Caucasus] and remove them; let them live as they please. On the other hand, you have to understand that if you let one [national group] do this, then the others will start making noises (shurshaniye). It's like the domino principle. So, you need to operate here not according to emotions; you can't just follow the feeling "let them all go to hell." (Interview with Evgeny, a 30-year-old sales manager for construction materials, in St. Petersburg)

In part, this suggests a continuation with previous polling that suggested up to half of Russians believed the Second Chechen War was fought to prevent the collapse of Russia as a country, while three quarters believed it was mainly to combat banditry (Trenin and Malashenko 2004, 51). ${ }^{14}$ Indeed, there was the sense among respondents that, in spite of much talk of Russia's size, strength, and power in modern discourse, many respondents keenly felt the country's internal weakness: "if you take one part away, then the whole thing will fall apart" (Interview with Sasha, a 28-year-old university lecturer in history, in St. Petersburg). The fear of a 1991-style unravelling underpins support for the current status quo, even if this seems to suggest the essential fragility of the current arrangements and doubts the Russian state's capacity to survive the loss of certain territories. One clear connection was the link of secession to chaos and violence. Given the past and present examples, one respondent suggested it was better to leave things be and let the Federal Center decide redistribution questions as they saw fit: "Ukraine is a very clear example. Look what happened in the Donbass: things fell apart, and it is all dog eat dog there (kak pauki v banke). The same thing would happen here if we started to separate some regions" (Interview with Ivan, a 55-year-old retired miner, in St. Petersburg).

The above offers evidence that memory of recent lived history acts as an important driver in the adoption of statist and security discursive frames. It is important to note here that much of the territorial conservatism is linked to concern about collapse. Rather than a confident expansionist imperial mentality with a clearly defined civilizational mission, Russian post-imperial consciousness is a "hold the fort" mentality: the desire to keep things as they are rather than expand or fundamentally redraw borders on ethno-cultural grounds. In other words, the statist and stability discourses are far more prevalent than ideas of national renewal, reform, or reconfiguration.

\section{Representations of Migrants: Soviet-Infused Normative Stances and Demands for Assimilation}

A second out-group emerging from my interviews was that of migrants: legal and illegal immigrant laborers from other parts of the post-Soviet space. A variety of authors have noted significant ambiguity to the integration of migrant workers in Russia, with state policies ranging from inclusivist integration policies to mass expulsions of migrants. Hutchings and Tolz $(2016,328)$ also discovered ambiguity in media coverage of the issue. This ambiguity is also visible in popular sentiment, with $53.3 \%$ agreeing migrant workers are a necessity in Russia and $42.5 \%$ supporting the idea that migrants should be sent back to their countries of origin. ${ }^{15}$ While there was some evidence of increasing xenophobic sentiment in Russia in the 2000s (Gudkov 2002; Pain 2004), it appears anti-migrant sentiment has declined in the last five years, especially in the post-Crimea period. ${ }^{16}$

Commenting on the "absence of a stable public consensus" on migration, Kosmarskaya and Savin noted how "pragmatism" on the demographic need for migrants coexisted with the "emotionally colored" desire "not to let them in" (2016, 156-159). A three-way divide in attitudes was found among respondents in this research, who were split between (1) those adhering to Soviet- 
style inclusivist visions of Russianness who tended to be more open to migrants, (2) those holding assimilationist views on Russianness who had more demanding stances toward migrants, and (3) those taking more hostile stances to migrant workers, using groupist language that focused on ethno-cultural difference.

One thing common to all three groups, however, was the idea that the management of migration in Russia today was in an abnormal state. The image of the ideal migrant and desirable interethnic relations was commonly taken from Soviet frames of reference. The claim that things were better in the USSR reflects the idea that mass migration is a new kind of phenomenon that did not exist previously: "Back then, we didn't have all this mixing. Every people lived in their own republic. It wasn't like now" (Interview with Anton, a 52-year-old ex-officer and small business owner, in St. Petersburg). Very few respondents argued druzhba narodov continued fully intact today, and many claimed they now lived in an atmosphere of increased intolerance and xenophobia. Many respondents revealed their understanding of how Soviet druzhba narodov worked: each narod was almost expected to stay in their home republic, rather than, for example, uproot and come to Russia to find work. Only a selected few were offered the chance to move. In addition, a Union-wide planned economy helped to balance out economic development across the country, meaning "more money was in the republics" and it was unnecessary to "come to Moscow or Nizhny Novgorod" for work (Interview with Julia, a 29-year-old chemist for a state company, in Nizhny Novgorod). Thus, "everybody was happy" during the Soviet "Friendship of Nations" because "it is not hard to love such people when they live on the territory of their own national republic" (Interview with Konstantin, a 27-year-old state municipal management specialist, in Moscow).

This brings us to a paradox in the way many respondents combined advocacy for Russia as a multinational state made up of diverse peoples with hostility to migrants and kavkaztsy. Support for multinationalism was often combined with the idea that "all peoples should stay in their homelands." This duality was present in Soviet Nationalities policy: the regime promoted a "friendship of nations" image but also strictly controlled migration flows with the propiska system. This way of managing multinationalism seems to have left strong traces up to today. Below, we find a good example of this tendency of combining support for a multi-ethnic country with a preference for restricting migration within the Russian Federation among its diverse peoples:

Russia is a pretty unique country... During the internal colonization of Eurasia... a very large amount of nationalities were accumulated... On the one hand, we are all inhabitants of one country and have one citizenship, but on the other hand we have great diversity. But I also think everyone should live on their own land... Together we are inhabitants of one huge country. On the other hand, I don't think we should mix everything up. (Interview with Evgeny, a 30-year-old sales manager for construction materials, in St. Petersburg)

The above combines Russian multinationalism (a continuation of Soviet internationalism) with indigenization (encouraging separate homelands for each national group who have a dominant role in their own republic and autonomous region). Perhaps this explains how respondents could comfortably combine unease toward newcomers to urban spaces-some of whom, such as the Chechens, may have come from within the Russian Federation-with support for the idea of Russia as a harmonic multinational country. One respondent made a distinct division between "native Russian peoples" (korennyye rossiiskie narodi) and "migrants" to explain her understanding of the situation:

The definition of Russia as a multi-ethnic country in our constitution alludes to the fact that many peoples (natsii) live here. I think Russia should be a state only for those peoples (narodov) that are native (korennyye) rossiyskie peoples, like the Tatars or those living in the far north. But Russia should not be a home for peoples like the Tajiks and all those immigrants that we have. (Interview with Ksenia, a 22-year-old law student, in Nizhny Novgorod) 
Thus, desires for a diverse and multi-ethnic country where most people stay in their own land reflects the continued influence of Soviet-infused frames of normality. One younger respondent offered a concise description of how the Soviet-era migrant (perceived as normal), who is a good fit with the urban cultural surroundings, contrasts to contemporary gastarbeiter (guest worker) that cannot be absorbed into the national body:

The migrant of the early nineties... would have been born in the USSR and had studied Russian. He would have been acquainted with Russian culture; I mean, he would be at a pretty high level. The kind of person who comes here today, the young folk, now I think $30 \%$ of them don't know Russian or Russian culture... If we take all this together with the problems of radical Islam in Central Asia, what we end up with is some kind of monster that arrives here. And there is already nothing we can do with him, but he is needed because we have low-paid jobs that nobody wants. (Interview with Victor, a 22-year-old International Relations student, in Nizhny Novgorod)

In other words, this new type of migrant is a monster that cannot be reformed, integrated, or made into the in-group. While the language in this example is rather extreme, other respondents suggested similar ideas about how today's migrants differ sharply from what their parents faced in the Soviet period and how the older Soviet system was more desirable. Overall, this way of thinking is difficult to reconcile with official statements by the state on Russia as a civilizational space of many peoples. Here, the apparently inclusivist definition of Russianness combines with uncompromising exclusivist demands for migrant integration through the absorption of Russian culture and language. This discourse is also tied up with very emotional language connected to disrespect and insolence. While a strong echo of Soviet internationalism is still present, especially in older respondents, for others this is challenged by an increasing sense of "our space" and "our towns" being "invaded" by "newcomers." The desire to either remove these migrants or force them to "follow our rules" represents a form of nationalism common to other European countries that need not be labelled ethnic or xenophobic; its concerns are often cultural, something that cannot be easily defined as purely ethnic or civic but as part of both (Shulman 2002, 559).

\section{Conclusion}

This article has examined some of the important features of mainstream nationalism and national identity in Russia. The lingering influence of seventy-four years of Soviet nation-building, which also claimed to transcend narrow inward-looking, parochial ethnic nationalism, and offer a nonWestern, nonliberal version of modernity, remains a recurring theme in conceptualizations of Russianness, nationalism, and patriotism. Soviet-infused frames of normality emerged across this sample, suggesting that the basic assumptions of Soviet nationality policy are still reproduced among some younger people. On the other hand, Soviet-style internationalism is challenged by a cultural nationalism that seeks to impose a clearer hierarchy of norms and behavior between Russians and migrants. Here, there are somewhat messy combinations, such as people mixing pride in Russia as a multinational country with the preference that people in the Russian Federation should stay in their ethnic homelands. Perhaps we should not find such eclectic combinations surprising, as they are common to many nationalist narratives around the world. ${ }^{17}$

This cultural nationalism is essentially part of a discourse on how their resources need to be spent on themselves rather than the Other: corrupt people in the state, migrants, the North Caucasus, the ethnic Russians or Russian-speakers living in neighbouring Post-Soviet states, and foreign adventures in Syria and Ukraine. It remains an open question how such sentiment will be managed, especially as antimigrant and anti-Kavkaz discourses remain prevalent while the state continues pushing the "Russia as a unique civilization" rhetoric, pursuing Eurasian economic integration projects and spending increasingly scarce national resources on the maintenance of the "Russian civilizational space." 
Which elements of the interview narratives, then, most resonated with state discourse? One key area is positive myths about Russia's multi-ethnic traditions, which are also often mentioned in Putin's speeches. The sense that Russia has no colonial or imperialist past to confront encourages the feeling that non-Russian national groups (or the malye narodi) are comfortable and content within the current Eurasian multi-ethnic family. Thus, Soviet-era hierarchies appear to have survived the post-Soviet transition period and are still reproduced in the imaginaries of younger people. A second point of overlap is statist narratives on stability and great power responsibility. This is a "hold the fort" sentiment that revolves around holding the great state together, independent from the West and the East, and resisting separatism from within and probes from without. The priority of forestalling ethnic separatism, interstate war, and state meltdown, clear in attitudes to the North Caucasus, reinforce the state-civilization identity by providing a sense of urgency and a constituent Other (those who resist this agenda, such as liberals or foreign powers). A third element of resonance is only partial: the cultural nationalism discourse, which shares some of the features of Western Europe's so-called 'populist' parties and has some overlap with state-promoted inclusive discourses, such as Medinsky's "Foundations of Cultural Policy," advocates civilizational unity through common absorption of Russian language and culture.

This brings us to how interview narratives deviate from state discourse. First, more elaborate ideological versions of "Russia as a state-civilization" did not resonate with respondents: there was little interest in concepts that flesh out Russia's civilizational distinctiveness such as Eurasianism, russkii mir, or Russia as the guardian of traditional values. Interestingly, Russian exceptionalism or uniqueness was articulated in very limited and pragmatic terms. Perhaps this lack of deeper articulation will reduce the mobilizing appeal and of long-term viability of the "state-civilization" narrative, especially in a context of economic stagnation and social pressures. In other words, discourses that emphasise how "our" resources should be spent on "our" people may successfully challenge the civilizational and geopolitical statist narrative over time, especially as excitement over Russian involvement in Ukraine and Syria fades into memory.

Furthermore, the hegemonic view of the russkie harmonically living alongside (and frequently absorbing) the peoples of Eurasia, which folds away ethnic and religious differences and perpetuates the notion of the ethnic Russian as "elder brother," may be problematic to regional stability. It is hard to believe that many among Russia's minorities would not challenge these narratives on multinational Russia. At the moment, however, it would appear that the narratives of the dominant ethnicity and multi-ethnic harmony normalizes the existing order in universalistic terms, de-problematizes the past, and works as a stabilizing factor in discourse on the nation.

Acknowledgements. The author would like to thank Kevork Oskanian, Susanna Rabow-Edling, and the two reviewers of the article for very helpful comments and critique while writing this article. Interviews were conducted with the help of an ERANET MUNDUS Doctoral Mobility Grant (2015-2016), which made extended fieldwork possible. The article was also written in the supporting working environment of the Institute of Russian and Eurasian Studies, where a version of this article was presented in April 2019 at an IRES Research Seminar.

Disclosure. Author has nothing to disclose.

\section{Notes}

1 Thus, understanding mainstream nationalism entails uncovering "hegemonic nationalist discourse." By "hegemonic," I mean it is agreed upon by the many from below, who internalize concepts promoted in state, intelligentsia, and media circles, constructing their own meanings through conversations and interactions with friends, colleagues, and family. It is nationalist in as far as it is made up of a set of claims about the nation. Finally, it is a discourse because it is made up of talk and words-a series of narratives, myths, and visions of normality.

2 This division maps onto the two historical names for Russia: Rus, the original ethnic heartland around Muscovy, and Rossiia, the greater or imperial Russia from the late sixteenth century 
onward (Wortman 2000, 7). What is more contentious is how far, in the current period, these two divisions map onto the civic-ethnic binary (for more discussion, see Teper 2015; Blakkisrud 2016). My own position is closer to that of Marlene Laruelle (2016b), who argues that, rather than reflecting ethnic nationalism, russkii is used in an imperial (rather than ethnic) sense to underline the unity of various Eastern Slav peoples in one civilizational space under one state. In other words, "Putin can both insist increasingly on russkii while continuing to claim the principle of Russia’s multinational character" (Laruelle 2016b).

3 In comparison to Nizhny Novgorod and St. Petersburg, interviews in Moscow mostly involved interviewing specific people connected to the topic of nationalism: academics, politicians, publicists, and journalists who have written on such matters. This is reflected in the article in as far as most quotes come from Nizhny Novgorod and St. Petersburg.

4 Russian demographer Natalia Zubarevich has called this "Russia One," into which she also includes towns with populations from 250,000 to $1,000,000$. Russia Two, on the other hand, covers small to medium-sized cities from 50,000 to 250,000 in population, which represents $30 \%$ of Russia's population (Zubarevich 2013,70). This zone is characterized by higher industrial employment and more dependency on public sector work than in Russia One, where there is far more entrepreneurial activity. Russia Three refers to Russia's rural heartlands: small settlements and villages with a population under 50,000, which make up $30 \%$ of the population (Zubarevich $2013,70)$. Here, agriculture, the public sector, and informal work are the main sources of employment. The final zone outlined by Zubarevich, Russia Four, refers to the ethnic republics on the periphery (South Siberia and Caucasus), which have some very specific features and make up only $6 \%$ of the population.

5 The main reason for these exclusions was the limited resources of this project. A larger, wellfunded, multiple-researcher project would be needed to examine regional, ethnic and socioeconomic differences in the absorption of nationalist discourse.

6 By which Shevel (2011) means the Kremlin vacillated between a civic and an ethno-cultural understanding of the nation.

7 As the cited authors also note, a comprehensive shift in either direction would be inadvisable on pragmatic grounds: the Western "civic" model is impractical due to popular and elite attitudes on the unsuitability of Western democratic models, while an "ethnic" turn would risk separatism and instability in the non-Russian regions. Indeed, the Kremlin has cracked down on Russia's "ethnic nationalists." Following the 2010 Manezhaya disturbances involving violence against migrants, restrictive legislation aimed to reduce nationalist violence (Teper 2018, 70). In the wake of the Crimean annexation, a wave of arrests brought down a number of prominent (and anti-Putin) Russian "ethnic" nationalists, such as Dmitri Demushkin and Aleksandr Belov (Meduza 2015).

8 This idea also found its way into "The Strategy of State Nationalities Policies to 2025," passed in 2012, which claimed that, "thanks to the unifying role of the Russian people (russkii narod), centuries-long intercultural and interethnic interactions, a unique cultural diversity and spiritual communality (dukhovnaya obshchnost') developed on the historic territory of the Russian state (rossiyskogo gosudarstva)" (Kremlin 2012).

9 As Putin declared in 2012, "Russia can and must play the worthy role that is dictated by her civilizational model, glorious history, geography, and cultural genome, in which there is an organic combination of the fundamental foundations of European civilization and the long experience of interaction with the East, where in the current moment new centers of economic power and political influence are forming" (Putin 2012b).

10 Here we must be careful in offering too direct a translation of $d u k h$ as "soul." in Russian, it covers a broader range of ideas, such as consciousness, the metaphysical, feelings, and the spirit within one's self.

11 Following Soviet academic traditions and popular practice, this position is founded on understanding the word "nation" (natsiia) as a synonym for "ethnic group" (Pain 2004, 16) and "nationalist" as a person obsessed with the interests of their own ethnic group. 
12 Levada polling over 2004-2016 shows these two groups currently in the lead over the following question: "Should we limit the number of X living on the territory of Russia?" Interestingly, in this period ratings for Jews (15-6\%), the Chinese (39-24\%), and the Vietnamese (39-19\%) dropped by roughly half (Levada 2016b). On the other hand, the same poll in 2018 showed a spike in the same ratings back nearer to 2004 levels for the Chinese and Vietnamese (Levada 2018).

13 The term cherniye (blacks) is a derogatory term used to describe people from the south, especially the Caucasus. Its use underwent a marked increase during the 1990's (Russell 2005, 106).

14 Respondents could choose more than one answer in this poll.

15 Data from 2013 NEORUSS research project; details available in Kolsto and Blakkisrud (2016).

16 From 2014-2017, indicators from Levada Centre polling showed a sharp drop in "xenophobic" sentiment (measured in responses to the question "which groups' presence on the territory should be restricted") (Levada 2017) 2018 polling, on the other hand, suggests this trend was very short-lived (Levada 2018).

17 Consider, for example, the paradoxical positions uncovered by Arlie Russell Hochschild (2016) in the "deep story" told by Louisiana Tea Party supporters, who supported deregulation of environmental protection while suffering the direct consequences of living in America's most polluted state.

\section{References}

Anderson, Benedict. 1991. Imagined Communities: Reflections on the Origin and Spread of Nationalism. London: Verso.

Berg, Lawrence. 2009. "Discourse Analysis.” In The International Encyclopaedia of Human Geography, edited by Rob Kitchin and Nigel Thrift, 215-221. Amsterdam: Elsevier Publishing.

Bezrogov, Vitaly. 2012. “If the War Comes Tomorrow': Patriotic Education in the Soviet and Post-Soviet Primary School.” In Soviet and Post-Soviet Identities, edited by Mark Bassin and Catriona Kelly, 113-128. Cambridge: Cambridge University Press.

Billig, Michael. 1995. Banal Nationalism. London: Sage Publications

Blakkisrud, Helge. 2016. "Blurring the Boundary between Civic and Ethnic: The Kremlin's New Approach to National Identity under Putin's Third Term.” In The New Russian Nationalism: Imperialism, Ethnicity and Authoritarianism 2000-2015, edited by P. Kolsto and H. Blakkisrud, 249-274. Edinburgh: Edinburgh University Press.

Calhoun, Craig. 1997. Nationalism. Buckingham: Open University Press.

Calhoun, Craig. 2007. Nations Matter: Culture, History, and the Cosmopolitan Dream. London: Routledge.

Chirikova, Alla. 2010. “The Power Vertical in the Assessments of Regional Elites." Russian Politics and Law 48 (1): 40-57.

Collias, Karen. 1990. “Making Soviet Citizens: Patriotic and Internationalist Education.” In Soviet Nationality Policies: Ruling Ethnic Groups in the USSR, edited by Henry R. Huttenbach, 73-93. London: Mansell Publishing.

Russian Security Council. 2014. "Doctrine of National Security up to 2020." http://static.kremlin.ru/media/events/files/ 41d527556bec8deb3530.pdf/. (Accessed February 20, 2020.)

Finlayson, Alan. 1998. "Ideology, Discourse and Nationalism." Journal of Political Ideologies 3 (1): 99-118.

Foreign Ministry of the Russian Federation. 2013. Konseptsiya vneshnei politiki Rossiiskoi Federatsii' [Foreign Policy Concept of the Russian Federation]. The Ministry of Foreign Affairs of the Russian Federation, February 12. https://www.mid.ru/en/ foreign_policy/official_documents/-/asset_publisher/CptICkB6BZ29/content/id/2542248. (Accessed February 20, 2020.)

Goode, J. Paul, and David R. Stroup. 2015. “Everyday Nationalism: Constructivism for the Masses.” Social Science Quarterly 96 (3): 717-739.

Goode, Paul. 2018. "Everyday Patriotism and Ethnicity in Today's Russia.” In Russia Before and After Crimea: Nationalism and Identity, 2010-2017, edited by Pål Kolstø and Helge Blakkisrud, 258-281. Edinburgh: Edinburgh University Press.

Gudkov, Lev. 2002. Russkii neotraditzionalizm i soprotivlenie peremenam [Russian Neo-Traditionalism and Resistance to Change]. In Mul'tikul'turalizm i transformatzija postsovetskih obshhestv [Multiculturalism and the Transformation of PostSoviet Society], edited by V. S. Malahova. and V. A. Tishkova, 124-147. Moscow: Institut etnologii i antropologii RAN.

Gudkov, Lev. 2015. "Resources of Putin's Conservatism." In Putin's Russia: How It Rose, How It Is Maintained and How It Might End, edited by Leon Aron. Washington, DC: American Enterprise Institute.

Hochschild, Arlie Russell. 2016. Strangers in Their Own Land: Anger and Mourning on the American Right. New York: The New Press.

Hosking, Geoffrey. 2006. Rulers and Victims: The Russians in the Soviet Union. Cambridge, MA: Harvard University Press.

Hutchings, Stephen, and Vera Tolz. 2016. "Ethnicity and Nationhood on Russian State-Aligned Television: Contextualising Geopolitical Crisis." In The New Russian Nationalism: Imperialism, Ethnicity and Authoritarianism 2000-2015, edited by Pål Kolstø and Helge Blakkisrud, 298-335. Edinburgh: Edinburgh University Press. 
Kolesnikov, Andrei. 2015. Russian Ideology After Crimea. Moscow: Carnegie Endowment for International Peace. http:// carnegie.ru/2015/02/25/ru-pub-59177. (Accessed May 23, 2019.)

Kosmarskaya, Natalya, and Igor Savin. 2016. "Everyday Nationalism in Russia in European Context: Moscow Residents' Perceptions of Ethnic Minority Migrants and Migration." In The New Russian Nationalism: Imperialism, Ethnicity and Authoritarianism 2000-2015, edited by Pål Kolstø and Helge Blakkisrud, 132-159. Edinburgh: Edinburgh University Press.

Kvale, Steinar. 1995. “The Social Construction of Validity.” Qualitative Inquiry 1 (1): 19-40.

Kremlin. 2012. Ukaz Prezidenta Rossiyskoy Federatsii o strategii gosudarstvennoy natsional'noy politiki Rossiyskoy Federatsii na period do 2025 goda [Presidential Order on the Strategy of State Nationality Policy in the Russian Federation until 2025]. Kremlin, December 19. http://kremlin.ru/acts/bank/36512/page/3. (Accessed May 23, 2019.)

Lavrov, Sergei. 2016. “A Historical Perspective of Russia's Foreign Policy” [Istoricheskaya perspektiva vneshney politiki Rossii]. Russia in Global Affairs, March 30. https://eng.globalaffairs.ru/number/Russias-Foreign-Policy-in-a-Historical-Perspec tive-18067. (Accessed May 23, 2019.)

Le Huérou, Anne. 2015. "Where Does the Motherland Begin? Private and Public Dimensions of Contemporary Russian Patriotism in Schools and Youth Organisations: A View from the Field." Europe-Asia Studies 67 (1): 28-48.

Levada Center. 2016a. Derzhavnost' i osobyy put' Rossii [Greatpowerness and Russia's Special Path]. December 12, 2016. https:// www.levada.ru/2016/12/12/derzhavnost-i-osobyj-put-rossii/. (Accessed February 20, 2020.)

Levada Center. 2016b. Intolerantnost' i ksenofobiya [Intolerance and Xenophobia]. October 11. https://www.levada.ru/2016/10/ 11/intolerantnost-i-ksenofobiya/. (Accessed February 20, 2020.)

Levada Center. 2017. Uroven' ksenofobii v Rossii dostig minimuma [The Level of Xenophobia in Russia Has Hit New Low]. August 23. https://www.levada.ru/2017/08/23/uroven-ksenofobii-v-rossii-dostig-minimuma/. (Accessed February 20, 2020.)

Levada Center. 2018. V Rossii vyrosli ksenofobnyye nastroyeniya [In Russia Xenophobic Sentiment Is Rising]. August 27. https:// www.levada.ru/2018/08/27/v-rossii-vyrosli-ksenofobnye-nastroeniya. (Accessed February 20, 2020.)

Laruelle, Marlene. 2015. "Patriotic Youth Clubs in Russia: Professional Niches, Cultural Capital and Narratives of Social Engagement.” Europe-Asia Studies 67 (1): 8-27.

Laurelle, Marlene. 2016a. "Russia as an Anti-liberal European Civilisation." In The New Russian Nationalism: Imperialism, Ethnicity and Authoritarianism 2000-2015, edited by Pål Kolstø and Helge Blakkisrud, 275-276. Edinburgh: Edinburgh University Press.

Laurelle, Marlene. 2016b. Misinterpreting Nationalism: Why Russkii is Not a Sign of Ethnonationalism. Policy Memo No. 416. PONARS Eurasia. http://www.ponarseurasia.org/ru/node/8218. (Accessed August 2, 2019.)

Laruelle, Marlene. 2017. "Is Nationalism a Force for Change in Russia?" Daedalus 146 (2): 89-100.

Marten, Kimberly. 2014. "Vladimir Putin: Ethnic Russian Nationalist." Washington Post, March 19. https://www. washingtonpost.com/news/monkey-cage/wp/2014/03/19/vladimir-putin-ethnic-russian-nationalist/. (Accessed Febuary 20, 2020.)

Meduza. 2015. Zapret dvizheniya "russkie" [The Banning of the Russkie Organization]. Meduza, October 28. https://meduza.io/ feature/2015/10/28/zapret-dvizheniya-russkie. (Accessed February 20, 2020.)

Ministry of Culture. 2015. "The Foundations of Cultural Policy.” Ministry of Culture. https://www.mkrf.ru/upload/mkrf/ mkdocs2016/OSNOVI-PRINT.NEW.indd.pdf. (Accessed February 20, 2020.)

Morrison, Alexander. 2016. Russia's Colonial Allergy. Eurasianet, December 19. https://eurasianet.org/russias-colonial-allergy. (AccessedMay 24, 2019.)

Newton, Julie. 2010. "Shortcut to Great Power: Russia in Pursuit of Multipolarity." In Institutions, Ideas and Leadership in Russian Politics, edited by Julie Newton and William Tompson, 88-115. London: Palgrave MacMillan.

Pain, Emil. 2004. Mezhdu imperiei i natsiei: modernistskii proekt i ego traditzionalistskaja al'ternativa $v$ natsional'noi politike Rossii [Between Empire and Nation: The Modernist Project and Its Traditionalist Alternative in the Nationality's Policies of Russia]. Moskva: Fond Liberal'naya Missiya Novoe Izdatel'stvo.

Pain, Emil. 2016. “The Imperial Syndrome and Its Influence on Russian Nationalism.” In The New Russian Nationalism: Imperialism, Ethnicity and Authoritarianism, 2000-2015, edited by Pål Kolstø and Helge Blakkisrud, 46-74. Edinburgh: Edinburgh University Press.

Panov, Petr. 2010. "Nation-building in Post-Soviet Russia: What Kind of Nationalism Is Produced by the Kremlin." Journal of Eurasian Studies 1: 85-94.

Petrov, Nikolay, and Darrell Slider. 2007. “Regional Politics.” In Putin's Russia: Past Imperfect, Future Uncertain, edited by Dale R. Herspring, 63-82. Lanham: Rowman \& Littlefield.

Ponarin, Eduard, and Michael Komin. 2018. "Imperial and Ethnic Nationalism: A Dilemma of the Russian Elite." In Russia Before and After Crimea: Nationalism and Identity, edited by Pål Kolstø and Helge Blakkisrud, 50-68. Edinburgh: Edinburgh University Press.

Putin, Vladimir. 2000. “Annual Address to the Federal Assembly of the Russian Federation.” President of Russia. http:// en.kremlin.ru/events/president/transcripts/21480. (Accessed May 24, 2019.)

Putin, Vladimir. 2012a. Rossiia: natsional'nyi vopros [Russia: The National Question]. Nezavisimaia Gazeta, January 23. http:// www.ng.ru/ politics/2012-01-23/1_national.html. (Accessed May 24, 2019.) 
Putin, Vladimir. 2012b. Rossiya sosredotachivayetsya - vyzovy, na kotoryye my dolzhny otvetit' [Russia Is Concentrating Challenges We Must Meet]. Izvestiya, January 16. https://iz.ru/news/511884. (Accessed February 20, 2020.)

Putin, Vladimir. 2013. "Meeting of the Valdai International Discussion Club." President of Russia, September 19. http:// en.kremlin.ru/events/president/news/19243 (Accessed May 24, 2019.)

Putin, Vladimir. 2018. "Meeting of the Valdai International Discussion Club.” President of Russia, October 18. http:// kremlin.ru/events/president/news/58848. (Accessed May 24, 2019.)

Russell, John. 2005. “Terrorists, Bandits, Spooks and Thieves: Russian Demonization of the Chechens before and since 9/11.” Third World Quarterly 26 (1):101-116.

Rutland, Peter. 2010. “The Presence of Absence: Ethnicity Policy in Russia.” In Institutions, Ideas and Leadership in Post-Soviet Russia, edited by Julie Newton and William Tompson, 116-136. Houndmills: Palgrave Macmillan.

Shulman, Stephen. 2002. "Challenging the Civic/Ethnic and West/East Dichotomies in the Study of Nationalism." Comparative Political Studies 35 (5): 554-585.

Shcherbak, Andrei, and Kristina Sych. 2017. “Trends in Russian Nationalities Policy.” Problems of Post-Communism 64 (6): 311-328.

Shevel, Oxana. 2011. "Russian Nation-building from Yel'tsin to Medvedev: Ethnic, Civic or Purposefully Ambiguous?” EuropeAsia Studies 63 (2): 179-202.

Smith, Anthony. 1986. The Ethnic Origins of Nations. Oxford: Blackwell.

Smith, Anthony. 1991. National Identity. Reno: University of Nevada Press.

Stepanova, Elena. 2015. “The Spiritual and Moral Foundation of Civilization in Every Nation for Thousands of Years': The Traditional Values Discourse in Russia.” Politics, Religion \& Ideology 16 (2-3): 119-136.

Teper, Yuri. 2015. “Official Russian Identity Discourse in Light of the Annexation of Crimea: National or Imperial?” Post-Soviet Affairs 32 (4): 378-396.

Teper, Yuri. 2018. "Kremlin's Post-2012 National Policies: Encountering the Merits and Perils of Identity-Based Social Contract." In Russia Before and After Crimea: Nationalism and Identity, edited by Pål Kolstø and Helge Blakkisrud, 68-93. Edinburgh: Edinburgh University Press.

The Economist. 2016. “Trump's World: The New Nationalism.” The Economist, November 19. https://www.economist.com/ leaders/2016/11/19/the-new-nationalism. (Accessed February 20, 2020.)

Trenin, Dmitri, and Alexey Malashenko. 2004. Russia's Restless Frontier: The Chechnya Factor in Post-Soviet Russia. Washington, DC: Carnegie Endowment.

Trenin, Dmitri. 2015. Rossiya i mir v XXI veke [Russia and the World in the 21st Century]. Moscow: Eksmo.

Van Herpen, Marcel H. 2016. Putin's Propaganda Machine: Soft Power and Russian Foreign Policy. Lanham: Rowman and Littlefield.

Verkhovsky, Aleksandr, and Emil Pain. 2012. “Civilizational Nationalism: The Russian Version of the 'Special Path.” Russian Politics and Law 50 (5): 52-86.

Yablokov, Ilya. 2014. "Pussy Riot as Agent Provocateur: Conspiracy Theories and the Media Construction of Nation in Putin's Russia.” Nationalities Papers 42 (4): 622-636.

Yablokov, Ilya. 2018. Fortress Russia. Cambridge: Polity Press.

Welsh, Elaine. 2002. “Dealing with Data: Using NVivo in Qualitative Data Analysis.” Forum: Qualitative Social Research 3 (2).

Wortman, Richard. 2000. Scenarios of Power: Myth and Ceremony in Russian Monarchy from Peter the Great to the Abdication of Nicholas II. Princeton, NJ: Princeton University Press.

Zubarevich Natalya. 2013. “Four Russias: Human Potential and Social Differentiation of Russian Regions and Cities.” In Russia 2025, edited by Maria Lipman and Nikolay Petrov, 67-85. London: Palgrave Macmillan.

Cite this article: Blackburn, M. 2021. Mainstream Russian Nationalism and the "State-Civilization" Identity: Perspectives from Below. Nationalities Papers 49: 89-107, doi:10.1017/nps.2020.8 